\title{
Coronary flow reserve: a new target for treating hypertension
}

\author{
Hypertension Research (2009) 32, 316; doi:10.1038/hr.2009.15; published online 13 March 2009
}

Arterial hypertension is associated with an increased risk of cardiovascular morbidity and mortality. Although this is the consequence of several pathways, the common mechanism is the functional and anatomic remodeling in blood vessels, not only in the larger arteries, but in the microcirculation as well. In fact, long before the clinical manifestations of hypertension, the microcirculation is affected. ${ }^{1}$ This is the reason why hypertensive patients frequently have signs and symptoms of myocardial ischemia, despite angiographically normal coronary arteries. ${ }^{2}$ The current guidelines recommend that blood pressure control should be achieved as soon and effectively as possible to reduce cardiovascular outcomes. $^{3}$

As a result, it is likely that use of antihypertensive agents that improve coronary flow reserve, regardless of blood pressure reduction, will translate into better results. Recently, Hinoi et al. ${ }^{4}$ compared the effect of an angiotensin receptor blocker, telmisartan, with that of a calcium channel blocker, nifedipine, on coronary flow reserve among essential hypertensive patients without left ventricular hypertrophy. In this study, a total of 40 consecutive essential hypertensive patients were randomized daily to $40 \mathrm{mg}$ telmisartan or $20 \mathrm{mg}$ nifedipine coatcore treatment. After 12 weeks of treatment, the telmisartan and nifedipine groups showed similar declines in blood pressure. However, interestingly, at the study end, coronary flow reserve was improved in the telmisartan group ( $2.4 \pm 0.4$ to $2.9 \pm 0.4 ; P<0.01)$, but not in the nifedipine group $(2.5 \pm 0.3$ to $2.5 \pm 0.3 ; P=\mathrm{NS})$. Is this effect associated only with telmisartan or by contrast, could this effect be extended to other inhibitors of rennin-angiotensin system?

It has been reported that angiotensin II, through several mechanism that include vasoconstriction, endothelial dysfunction, oxidative stress, release of growth factors, or cell growth and migration, has a core role at the beginning of these vascular alterations. ${ }^{5} \mathrm{~A}$ recent clinical trial compared the effects of candesartan $v$ s. placebo on the coronary flow reserve after 3 months of therapy in a hypertensive population. ${ }^{6}$ This study showed that candesartan improved the coronary flow reserve in these patients and notably, this improvement was not related to blood pressure control or to left ventricular mass index regression. Moreover, the effects of candesartan were higher in those patients with a lower baseline coronary flow reserve.

All these data show that the angiotensin receptor blockers have a beneficial effect beyond blood pressure reduction, ${ }^{7}$ and importantly, this effect begins likely before other antihypertensive agents do, as shown by the effect on coronary flow reserve.

\footnotetext{
Vivencio Barrios ${ }^{1}$, Carlos Escobar ${ }^{2}$ and Rocio Echarri ${ }^{3}$

${ }^{1}$ Department of Cardiology, Hospital Ramón y Cajal, Madrid, Spain;

${ }^{2}$ Department of Cardiology, Hospital Infanta Sofía, Madrid, Spain and ${ }^{3}$ Department of Nephrology, Hospital Infanta Sofía, Madrid, Spain

E-mails: vbarriosa@meditex.esor vbarrios.hrc@salud.madrid.org
}

1 Palombo C, Kozakova M, Magagna A, Bigalli G, Morizzo C, Ghiadoni L, Virdis A, Emdin M, Taddei S, L'Abbate A, Salvetti A. Early impairment of coronary flow reserve and increase in minimum coronary resistance in bordeline hypertensive patients. J Hypertens 2000; 18: 453-459.

2 Houghton JL, Frank MJ, Carr AA, von Dohlen TW, Prisant LM. Relations among impaired coronary flow reserve, left ventricular hypertrophy and thallium perfusion defects in hypertensive patients without obstructive coronary artery disease. J Am Coll Cardiol 1990; 15: 43-51.

3 Mancia G, De Backer G, Dominiczak A, Cifkova R, Fagard R, Germano G, Grassi G, Heagerty AM, Kjeldsen SE, Laurent S, Narkiewicz K, Ruilope L, Rynkiewicz A, Schmieder RE, Boudier HA, Zanchetti A, Vahanian A, Camm J, De Caterina R, Dean V, Dickstein K, Filippatos G, Funck-Brentano C, Hellemans I, Kristensen SD, McGregor K, Sechtem U, Silber S, Tendera M, Widimsky P, Zamorano JL, Erdine S, Kiowski W, Agabiti-Rosei E, Ambrosioni E, Lindholm LH, Viigimaa M, Adamopoulos S, Agabiti-Rosei E, Ambrosioni E, Bertomeu V, Clement D, Erdine S, Farsang C, Gaita D, Lip G, Mallion JM, Manolis AJ, Nilsson PM, O'Brien E, Ponikowski P, Redon J, Ruschitzka F, Tamargo J, van Zwieten P, Waeber B, Williams B, Management of Arterial Hypertension of the European Society of Hypertension; European Society of Cardiology. 2007 Guidelines for the Management of Arterial Hypertension: The Task Force for the Management of Arterial Hypertension of the European Society of Hypertension (ESH) and of the European Society of Cardiology (ESC). J Hypertens 2007; 25: 1105-1187.

4 Hinoi T, Tomohiro Y, Kajiwara S, Matsuo S, Fujimoto Y, Yamamoto S, Shichijo T, Ono T. Telmisartan, an angiotensin II type 1 receptor blocker, improves coronary microcirculation and insulin resistance among essential hypertensive patients without left ventricular hypertrophy. Hypertens Res 2008; 31: 615-622.

5 Schiffrin EL, Park JB, Intentan HD, Touyz RM. Correction of arterial structure and endothelial dysfunction in human essential hypertension by the angiotensin antagonist losartan. Circulation 2000; 101: 1653-1659.

6 Tomás JP, Moya JL, Barrios V, Campuzano R, Guzman G, Megías A, Ruiz-Leria S, Catalán P, Marfil T, Tarancón B, Muriel A, García-Lledó A. Effect of candesartan on coronary flow reserve in patients with systemic hypertension. J Hypertens 2006; 24: 2109-2114.

7 Barrios V, Escobar C. Antihypertensive agents: are all of them equal? South Med J 2008; e-pub ahead of print 9 July 2008. 